\title{
Field observations of wave-induced headland rips
}

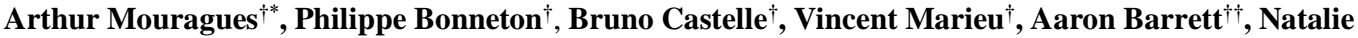 \\ Bonneton $^{\dagger}$, Guillaume Detand ${ }^{\dagger}$, Kevin Martins ${ }^{\dagger}$, Jak McCarroll ${ }^{\dagger \dagger}$, Denis Morichon ${ }^{\S}$, Timothy Poate ${ }^{\dagger \dagger}$, \\ Isaac Rodriguez Padilla ${ }^{\dagger}$, Tim Scott ${ }^{\dagger \dagger}$, Damien Sous ${ }^{\$} \$$
}

†Université de Bordeaux ${ }^{\dagger}$ University of Plymouth $\quad$ §Université Pau et Pays de l’Adour $\$$ Université de Toulon, Aix Mars CNRS; UMR 5805 EPOC Coastal Processes Research Group E2S UPPA, SIAME Université; CNRS; IRD; Medite ...

Pessac, France Plymouth, UK Anglet, France Institute of Oceanography (MIO) La Garde, France

\begin{abstract}
Mouragues, A.; Bonneton, P.; Castelle, B.; Marieu, V.; Barrett, A.; Bonneton, N.; Detand, G.; Martins, K.; McCarroll, J.; Morichon, D.; Poate, T.; Rodriguez Padilla, I.; Scott, T., and Sous, D., 2020. Field observations of wave-induced headland rips. In: Malvárez, G. and Navas, F. (eds.), Proceedings from the International Coastal Symposium (ICS) 2020 (Seville, Spain). Journal of Coastal Research, Special Issue No. 95, pp. 1-5. Coconut Creek (Florida), ISSN 0749-0208.
\end{abstract}

Most of rip-current field experiments have focused on persistent rips along rip-channeled sandy beaches or transient rips along reasonably alongshore-uniform surf-zone morphology, while experiments on rip flowing against structures are scarce. In October 2018, a 3-week field experiment was performed at Anglet beach, SW France, aiming at examining the dynamics of high-energy rip currents in complex settings. The beach is barred with prominent inherited geology, characterized by the presence of a $500-\mathrm{m}$ headland and a natural submerged reef. A large array of in-situ instruments was deployed to capture the temporal and spatial variability of rip flow circulations, including ADCPs, surf-zone drifters and video monitoring. The latter allowed to identify a wide range of rip-flow patterns. Among these patterns, a high-intensity rip current flowing against the headland was a dominant feature for obliquely incident waves. Such a boundary rip current was driven by the deflection of the longshore current against the headland, peaking at 0.7 $\mathrm{m} / \mathrm{s}$ (5-min time- and depth-averaged) 800-m offshore in 12-m depth for a moderate storm event with 4-m obliquely incident waves. Very-low-frequency $(\mathrm{O}(1 \mathrm{~h})$ and $\mathrm{O}(30 \mathrm{~min}))$ fluctuations of this rip current were observed around low tide. Measurements of the vertical structure of the rip reveal that the deflection rip was more vertically-sheared as the water depth increases, with higher velocities near the surface, which is typical of a theoretical rip head structure.

ADDITIONAL INDEX WORDS: Field experiment, nearshore circulations, headland rip, vertical structure.

\section{INTRODUCTION}

Wave breaking is the primary process driving nearshore currents and sediment transport along wave-exposed coasts. Alongshore variations in broken wave energy dissipation enforced by alongshore variability in depth of the beach drive rip current circulation which are typically composed of counter rotating cells. On open sandy beaches, such circulation patterns have received much attention (e.g. MacMahan et al., 2010a). However, such a circulation becomes increasingly complex as the presence of geological inheritance (e.g. headlands, rocky bed) becomes important. Headland-bounded embayed beaches, which are ubiquitous along rugged coastline, are a striking example of geologically-constrained environments. They are known to host a mixture of circulation types which typically include boundary rips (shadow and deflection rips) and channel rips (Castelle et al., 2016). While rip flow patterns along embayments have been previously observed (e.g. Loureiro et al., 2012b) and modelled for idealized cases (Castelle and Coco, 2012, 2013), only a few field studies have been carried out in such embayments (e.g. McCaroll et al., 2014). Amongst these field data-based studies, only a handful have focused on boundary rips (Coutts-Smith, 2004), which are also sometimes referred to as headland rips. In addition, these studies relied on relatively scarce depth-averaged velocity measurements and/or are associated with weaklyvarying and/or weakly-energetic offshore wave conditions. Yet, boundary rips are known to potentially extend much further seaward than most of the other rip types (Castelle and Coco, 2013), and are therefore critical to both beach safety for beachgoers and water/sediment exchange between the nearshore and the inner shelf. Accordingly, improving our understanding on boundary rip dynamics is of paramount importance.

This paper presents a comprehensive 3-week field experiment carried out in one of Anglet beaches (SW France, Figure 1), La Petite Chambre d'Amour beach (PCA beach), during October 2018. This field experiment aimed at collecting a wide range of measurements in order to investigate wave-induced circulations in a strongly geologically-constrained environment, with the presence of a prominent submerged reef and a rocky headland. A detailed analysis of the main circulation patterns is given by Mouragues et al. (in prep.). In the present paper, the full setup of the experiment is firstly presented. Then, the temporal and 
vertical variability of a high-energy deflection rip induced by obliquely incident storm waves is addressed.

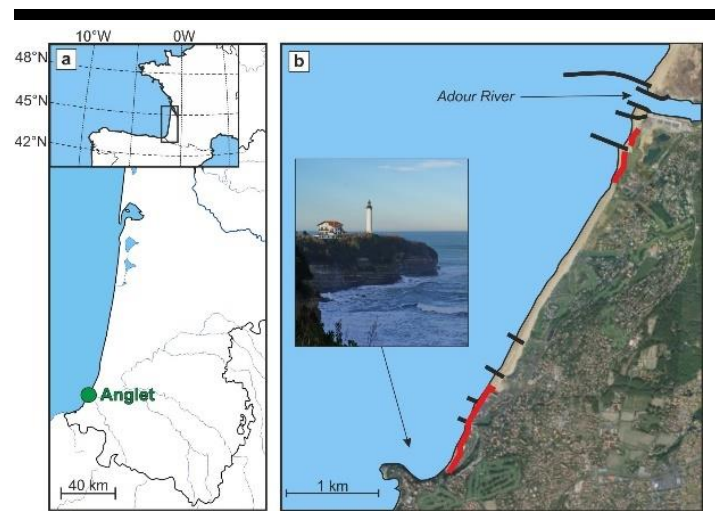

Figure 1. (a): Location of Anglet along the Aquitaine coast (SW France). (b): Map of Anglet beaches showing the location of the groins (black thick lines) and photo of the headland bounding the southern part of PCA beach.

\section{Field Site}

\section{METHODS}

The field experiment was performed in October 2018 (from the $3^{\text {rd }}$ to the $26^{\text {th }}$ ) at PCA beach in Anglet, located on the Basque Coast, SW France (Figure 1). The Basque Coast is a high-energy wave environment which is predominantly exposed to Atlantic swells coming from the W-NW direction and can also rarely experience more variable locally-generated wind waves (Abadie et al., 2005). The annual mean significant wave height and peak period are $H_{S}=1.57 \mathrm{~m}$ (up to $10 \mathrm{~m}$ during severe storms) and $T_{P}$ $=10 \mathrm{~s}$, respectively. The tide is meso-macro and semi diurnal. As opposed to the well-documented open sandy beaches further north along the Aquitaine coast, the rugged Basque coastline features beaches which are mostly characterized by prominent inherited geology. PCA beach is the most southern part of a 4-km long sandy embayment facing WNW which comprises 6 groins (Figure 1b). The beach is composed of medium to coarse (D50 $2 \mathrm{~mm})$ sand with a steep beach face $(\sim 1 / 10)$. For more information on Anglet beach setting and beach morphodynamics, the reader is referred to Huguet et al. (2016). During the field experiment, the morphology of northern PCA beach was relatively uniform alongshore, while the southern part longshorevariable owing to geological features. In particular, a natural submerged reef is located approximately $150 \mathrm{~m}$ from the mean sea level shoreline, and the Saint-Martin rocky headland extends approximately $500 \mathrm{~m}$ offshore, bounding the southern end of the field site. Such features are expected to induce alongshore variations in wave breaking (see Figure 2e showing waves breaking over the reef), with the headland also potentially guiding boundary rips. An array of instruments was therefore deployed at the southern end of PCA to explore the spatial and temporal variability of surf zone circulations in this area, which are described below.

\section{Eulerian Mesurement Data}

Four Acoustic Doppler Current Profilers (ADCPs) were arrayed across the field site at strategic locations to capture the circulation structure. SIG1 (Nortek Signature 500 kHz; 4 Hz), SIG2 (Nortek Signature 1000 kHz; 8 Hz), SIG3 (Nortek Signature 1000 kHz; 1 $\mathrm{Hz}$ ) and AQ (Nortek Aquadopp; $1 \mathrm{~Hz}$ ) were deployed far offshore (800-m offshore), few meters off the reef, along the headland and in the vicinity of the reef, respectively (Figure 2a). All sensors continuously recorded pressure and velocities along the water column (see Figure $3 \mathrm{~d}$ for deployment schedule of each sensor).

\section{Surfzone Drifters}

Six GPS-equipped surf-zone drifters were deployed in the vicinity of the reef in order to provide a greater spatial coverage of surface current circulations than Eulerian measurements (Figure 3d). The drifters were designed to be partially submerged which allowed them to track the surface currents with minimized surfing behavior (i.e. being caught by a bore). Such a design has been successfully used in previous works to record rip current circulations occurring in various environments (e.g. MacMahan et al., 2010a; McCarroll et al., 2014; Scott et al., 2016). The drifter location was continuously tracked by GPS, logged at 2.5 $\mathrm{Hz}$ and transmitted to a shore station providing a real-time information of the drifter positions, which was used to optimize drifter deployment and removal. Because of the energetic conditions and prominent rocks posing safety issues to the field measurement staff, the drifters were seeded using a rigid inflatable boat (on the $16^{\text {th }}$ and $17^{\text {th }}$ ), a jet ski (on the $18^{\text {th }}, 19^{\text {th }}$ and $23^{\text {th }}$ ) or were manually seeded by swimmers during lower energy conditions (on the $22^{\text {th }}$ ). Drifters were manually retrieved when they washed ashore and by the offshore team on the boat/jet ski when required. All drifter seeding and recovery hours were logged by the shore team to help the post-processing. On the $16^{\text {th }}$ and $17^{\text {th }}$, the energetic wave conditions (offshore $H_{S}=2 \mathrm{~m}$; Figure 3a) and the preliminary tests of deployment strategies did not allow to collect enough data for further analysis. During the other days of deployment (on the $18^{\text {th }}, 19^{\text {th }}, 22^{\text {th }}$ and $23^{\text {th }}$ ), the jet ski and manual seeds allowed to deploy and recover drifters quickly and efficiently. These four days provided sufficient data to study several representative surface current circulation patterns.

\section{Video Data}

In addition to the permanent video station installed in 2013 (Huguet et al., 2016), a video camera was installed to provide high-frequency images of the field. They provided useful qualitative spatial and temporal insights into rip flow circulation. This fixed camera was installed at the top of Biarritz lighthouse, located at the tip of the headland (Figures $2 \mathrm{a}$ and $\mathrm{b}$ ). The camera 
was situated approximately $70 \mathrm{~m}$ above the mean sea level and about $250 \mathrm{~m}$ away from the reef. The camera was facing ENE and recorded images of the site at $1 \mathrm{~Hz}$. Images were rectified into local coordinates (cross-shore and longshore) using Ground Control Points (GCP) spatially distributed both on land and water. In order to look into mean current circulations, running-averaged videos were generated to filter out gravity waves and further emphasize surface currents through drifting foams and streaks. The camera had a relatively narrow angle of view which prevented from monitoring circulations across the entire field site, especially the headland outlet. A camera-equipped Unmanned Aerial Vehicle (UAV) was also used during drifter deployment days (Figure 3d) to capture the full extent of circulations. The UAV-mounted camera allowed to record images at different points of view (see for instance Figure 2c).

\section{Topo-bathymetric Surveys}

Two bathymetric surveys of PCA beach were conducted on the $26^{\text {th }}$ of June 2018 and on the $5^{\text {th }}$ of October 2018. The first survey was collected using a multi-beam echo-sounder for accurately measuring the fixed bed morphology (e.g. the reef and the complex underwater morphology bordering the headland). A second survey was carried out in order to record the sandy bed morphology of the field site just prior to the measurement period. This last survey was performed with a single-beam echo-sounder and covered a larger area, providing data up to $400 \mathrm{~m}$ off the headland and approximately $800 \mathrm{~m}$ in the alongshore direction. Both bathymetries were obtained through Real Time Kinematic Global Positioning System (RTK-GPS) surveying from a boat. Areas along the headland were too hazardous to be surveyed due to breaking waves and exposed rocks. Such uncovered areas were retrieved by photogrammetry using the UAV at spring low tide. Data collected by the UAV were geo-referenced using several GCPs spatially distributed within the field site which locations were measured using a Post Processed Kinematic Differential GPS (PPK-DGPS). PPK-GPS positions were then adjusted into real world coordinates using corrections from a reference station located in Anglet airport, less than $3 \mathrm{~km}$ away from the field site. Finally, both the upper and intertidal beach topography were surveyed at low tide using the same PPK-DGPS which was carried in by walk. Combination of bathymetric and topographic surveys resulted in a comprehensive bathy-topo map of the site (see Figure 2a).

\section{Morphological Settings}

During the field experiment, the sandy bed morphology of the northern part of PCA beach was reasonably uniform alongshore (Figure 2a), corresponding to a low-tide terrace beach state according to the classification of Wright and Short (1984). Visual inspection of the beach and video images indicate that the beach morphology barely evolved throughout the experiment. Wave- induced circulations were therefore mainly controlled by the geological features (headland and reef). Figures 2d,e shows Google Earth images of the complex underwater morphology, depicting the reef shape and dimension (Figure 2d) and its control on wave breaking (Figure 2e). The headland edge and corner are mostly composed of rocks that can be exposed at low tide while the area between the headland edge and the reef is mainly composed of sand.

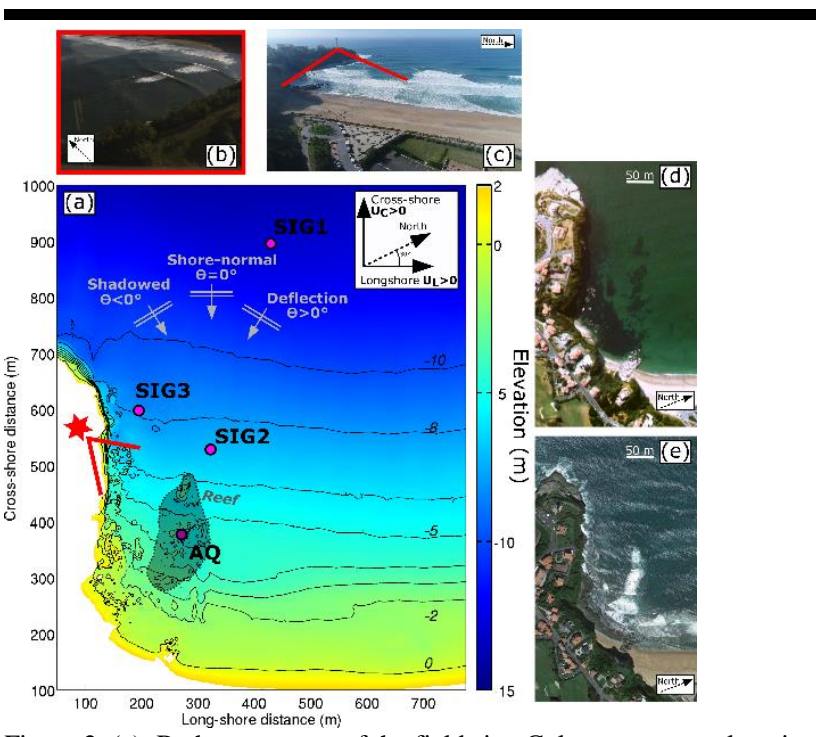

Figure 2. (a): Bathy-topo map of the field site. Color represents elevation (m) in NGF-IGN69 (Global French Levelling). Magenta points indicate the location of each sensor. The shaded area and the red star show the location of the reef and the lighthouse, respectively. Red lines indicate the headland-based camera view angle. (b) Example of a raw image recorded by the headland-based camera. (c) Example of a raw image recorded by the camera-equipped UAV. (d) and (e) Google Earth images showing the headland and the submerged reef during low-energy wave conditions (d) and moderate-energy conditions (e).

\section{Offshore Wave Conditions}

\section{RESULTS}

A permanent directional wave buoy moored in 50-m water depth and located 5-km offshore of Anglet measured, every 30 min, the offshore wave height, period and angle of incidence during the measurement period (Figure 3). PCA beach was exposed to a wide range of incident wave conditions during October 2018, from highly-oblique storm conditions to shorenormal low-energy wave conditions. Overall, the field experiment was characterized by relatively energetic wave conditions (average $H_{S}$ of $1.5 \mathrm{~m}$ ) with several high-energy wave events $\left(H_{S}>2 \mathrm{~m}\right)$. These wave events were also characterized by different offshore wave periods $\left(6<T_{P}<15 \mathrm{~s}\right)$ and angle of incidence relative to the shore normal $\left(-23<\theta_{P}<27^{\circ}\right)$. The corresponding sign of $\theta_{P}$ is shown in Figure 2a. One striking event is the very oblique storm on the $7^{\text {th }}\left(H_{S}=4 \mathrm{~m}\right.$ and $\left.\theta_{P}=27^{\circ}\right)$ 
which will be detailed later in the paper. Tide range varied from spring (tidal range $\sim 4.4 \mathrm{~m}$ ) to neap (tidal range $\sim 1.1 \mathrm{~m}$ ).

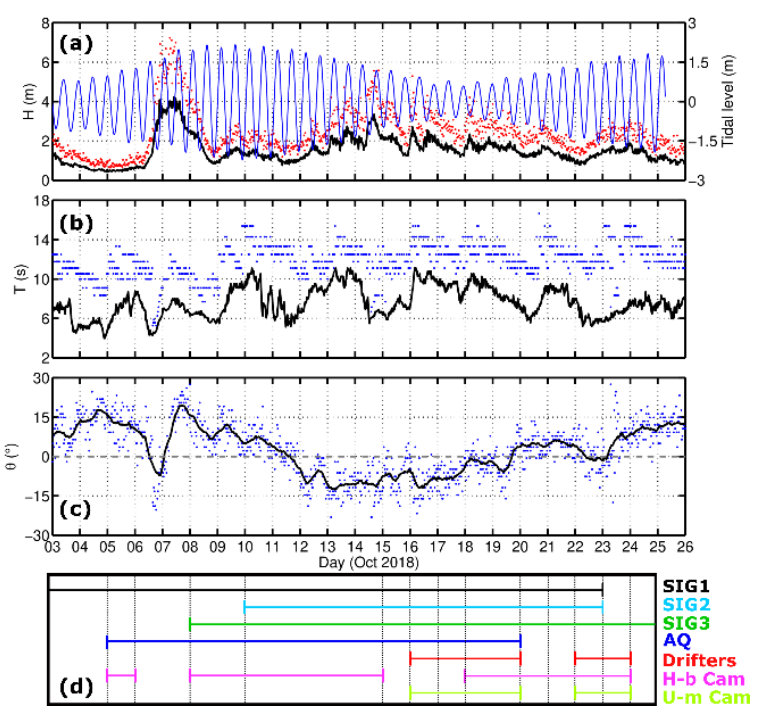

Figure 3. Offshore wave and tide conditions during the field experiment. (a): Tidal level (blue line), significant wave height $\left(H_{S}\right.$; black line) and maximum wave height $\left(H_{\max }\right.$; red dots). (b) Peak wave period ( $T_{P}$; blue dots) and mean wave period ( $T_{m 02}$; black line). (c) Peak wave incidence relative to the shore normal $\left(\Theta_{P}\right.$; blue dots) and its $12 \mathrm{~h}$-averaged values (black line). (d) Deployment schedule for each measurement item. H-b Cam and U-m Cam stand for the headland-based and the UAV-mounted camera, respectively.

\section{Circulation Patterns}

An extensive analysis of nearshore circulation is provided in Mouragues et al. (in prep), showing that a slight change in offshore wave conditions (mostly $\Theta_{P}$ and $H_{S}$ ) or tide elevation could dramatically alter circulation patterns across the entire field site. Depending on $\theta_{P}$, three main circulation regimes were depicted: (1) shadowed configuration $\left(\theta_{P}<0\right)$ which is characterized by transient rip-cell circulations on the reef and a longshore current flowing away from the headland; (2) shorenormal configuration $\left(\Theta_{P}=0\right)$ with circulations dominated by cross-shore flow in the surf zone, and transient circulations at the outer surf zone and (3) deflection configuration $\left(\theta_{P}>0\right)$ which is characterized by the deflection of the longshore current against the headland. The latter typically leads to an offshore-directed current flowing against the headland. This deflection rip was found to extend very far offshore even for low- to moderateenergy waves (at least $1000-\mathrm{m}$ offshore for $H_{S}=1.5 \mathrm{~m}$ from drifter measurements). Such a deflection rip was also measured during very oblique storm conditions, which is discussed below.

\section{High-energy Deflection Rip}

The most offshore ADCP (SIG1; located 800-m offshore) recorded velocity and pressure over the whole measurement period (Figure $3 \mathrm{~d}$ ). The 20-min time- and depth-averaged velocity was rather weak (up to $0.2 \mathrm{~m} / \mathrm{s}$ ) during the entire experiment, except during the most energetic and oblique wave event, on the $7^{\text {th }}$, when 20 -min time-averaged offshore velocities peaked at approximately $0.5 \mathrm{~m} / \mathrm{s}$ (see Mouragues et al. in prep.).

This very oblique and highly-energetic wave event $\left(H_{S}=4 \mathrm{~m}\right.$ and $\theta_{P}=27^{\circ}$ ) induced a strong deflection rip flowing from the surf zone to a distance offshore which is virtually unknown (at least 800-m offshore where SIG1 is located). Figure 4a shows the 5-min time- and depth-averaged (deflection rip velocity) and the instantaneous depth-averaged (wave orbital velocity) cross-shore velocity measured by SIG1 during this extreme event. The tidal modulation of the deflection rip is ubiquitous, with increasing velocity as the water depth decreases. At low tide, the deflection rip is intense and reaches $0.7 \mathrm{~m} / \mathrm{s}$ while absolute orbital velocity peaks at approximately $3 \mathrm{~m} / \mathrm{s}$. Figure 4 a also clearly displays strong and narrow very-low-frequency pulsations of the deflection rip with characteristic periods of around an hour and half an hour. Such a high-energy deflection rip is often termed as mega rip and has only been observed using digital imagery (Loureiro et al., 2012b) or scarcely measured (Coutts-Smith, 2004). To the author's knowledge, the present study is the first comprehensive measurement of a mega rip.

Figure $4 \mathrm{~b}$ represents the vertical profile of instantaneous crossshore velocity time-averaged over low tide (between 6 am and 10 am) and over high tide (between 12 am and $4 \mathrm{pm}$ ). The latter highlights the vertical variability of the deflection rip, with more depth-uniform and intense velocities at low tide $(0.27 \mathrm{~m} / \mathrm{s}$ close to the bottom and $0.39 \mathrm{~m} / \mathrm{s}$ near the surface), and less intense current with more vertical shear at high tide (near-zero close to the bottom and $0.28 \mathrm{~m} / \mathrm{s}$ near the surface). Such a depth variation pattern is in line with the very few studies focusing on the vertical structure of rip currents. To date, the only extensive measurement of the vertical structure of currents has been made by Haas and Svendsen (2002) who focused on a laboratory channel rip current. They measured a depth-uniform rip current inside a channel (rip neck) becoming increasingly depth variable offshore in the rip head, which has been satisfactorily reproduced by a quasi-3D circulation model in Haas and Svendsen (2000). The present study reveals the vertical variability of a rip current based on extensive field data. The vertical structure of rip current circulation is critical to sediment transport (near-bottom velocities) and transport and dispersion of tracers and floating matters (surface currents). Accordingly, the commonly-used depth-integrated circulation models may not be reliable in such settings. 

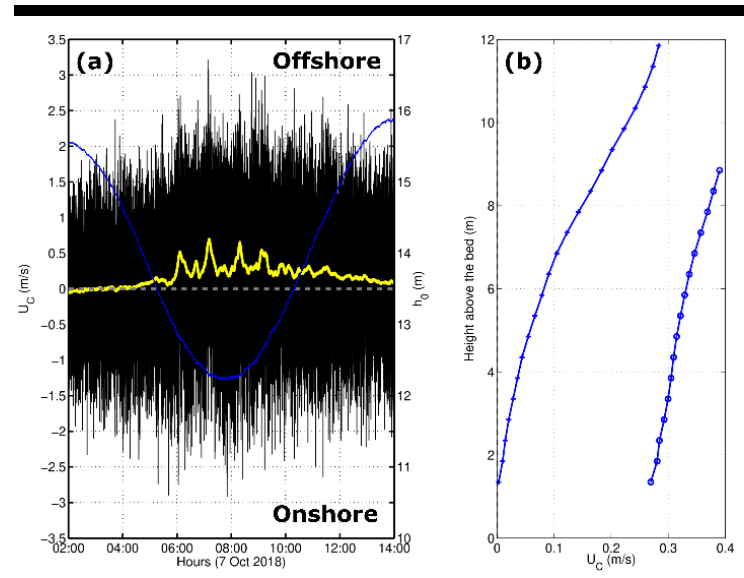

Figure 4. Cross-shore velocity $\left(U_{C}\right)$ and pressure measured by SIG1 during very oblique storm conditions $\left(H_{S}=4 \mathrm{~m}\right.$ and $\left.\theta_{P}=27^{\circ}\right)$. (a) Instantaneous (black), 5-min time-averaged (yellow) depth-averaged $U_{C}$ and pressure (blue). (b) Vertical profile of instantaneous $U_{C}$ timeaveraged over low (circles) and high (crosses) tide.

\section{CONCLUSIONS}

A 3-week extensive field experiment aiming at characterizing wave-induced circulations in a presence of a rocky headland and a natural reef was performed at PCA beach. A large array of measurement techniques has been deployed in order to capture the full extent of rip-cell circulations which were predominantly controlled by the headland and the reef. A large variability of circulation patterns was observed during the experiment, particularly during highly-oblique storm conditions. For such conditions, an intense deflection rip associated with very-lowfrequency pulsations at low tide was measured 800-m offshore. This high-energy rip was also found to be strongly depth-varying, especially at high tide with higher velocities near the surface, providing a new insight of what is often referred to as mega rips. It is anticipated that this unique dataset will help improving our understanding and modelling capacities of nearshore circulations occurring in complex environments.

\section{ACKNOWLEDGMENTS}

The Ph.D. of A. Mouragues is cofounded by a DGA-Region Nouvelle Aquitaine scholarship. This study has received financial support from Region Nouvelle Aquitaine (contract $\mathrm{n}^{\circ}$ 20171R20107) and was carried out as part of the project MEPELS (contract $\mathrm{n}^{\circ} 18 \mathrm{CP} 05$ ), performed under the auspices of the DGA, and led by SHOM. PCA beach is a field site labelled by SNO Dynalit (CNRS-INSU) which provided additional financial support for the experiment. The authors wish to thank Phares et Balises for providing access to the lighthouse and to lifeguard's representative (Syndicat Mixte de la Gestion de la Baignade Landaise and Guides des Bains Angloys) for providing jet-ski pilots and safety support during drifter deployment. The authors are also thankful to CASAGEC for collecting the 2018 June bathymetric survey and Aymeric Jouon for supervising further bathymetry measurements and helping with drifter recovery.

\section{LITERATURE CITED}

Abadie, S.; Butel, R.; Dupuis, H. and Briere, C., 2005. Paramètres statistiques de la houle au large de la côte sud-aquitaine. Comptes Rendus Geoscience, 337, 769-776.

Castelle, B. and Coco, G., 2012. The morphodynamics of rip channels on embayed beaches. Continental Shelf Research, $43,10-23$.

Castelle, B. and Coco, G., 2013. Surf zone flushing on embayed beaches. Geophysical Research Letters, 40, 2206-2210.

Castelle, B.; Scott, T.; Brander, R., and McCarroll, R.J., 2016. Rip current types, circulation and hazard. Earth-Science Reviews, 163, 1-21.

Coutts-Smith, A., 2004. The significance of mega-rips along an embayed coast. Ph.D. thesis, University of Sydney.

Haas, K. A. and Svendsen, I.A., 2000. Three-dimensional modeling of rip current systems. Res. Rep. CACR-00-06, Cent. For Appl. Coastal Res., Univ. of Del., Newark, Del.

Haas, K. A. and Svendsen, I.A., 2002. Laboratory measurements of the vertical structure of rip currents. Journal of Geophysical Research, 107 (C5), 3047.

Huguet, J.R.; Castelle, B.; Marieu, V.; Morichon, D. and De Santiago, I., 2016. Shoreline-sandbar dynamics at a highenergy embayed and structurally-engineered sandy beach: Anglet, SW France. J. Coast. Res., SI. 75, 363-397.

MacMahan, J.; Brown, J.; Brown, J.; Thornton, E.; Renier, A.; Stanton, T.; Henriquez, M.; Gallagher, E.; Morrison, J.; Austin, M.; Scott, T. and Senechal, N., 2010. Lagrangian flow behavior on an open coast rip-channeled beach: a new perspective. Marine Geology, 268, 1-15.

McCarroll, R.J.; Brander, R.; Turner, I.; Power, H. and Mortlock, T., 2014. Lagrangian observations of circulation on an embayed beach with headland rip current. Marine Geology, 355, 173-188.

Mouragues, A.; Bonneton, P.; Castelle, B.; Marieu, V, McCarroll, R.J.; Scott, T. and Sous, D., (in prep.). New insights into high-energy surf zone currents and headland rips at a geologically-constrained mesotidal beach.

Loureiro, C.; Ferreira, O. and Cooper J., 2012. Extreme erosion on high-energy embayed beaches: Influence of mega rips and storm grouping. Geomorphology, 139-140, 155, 171.

Scott, T.; Austin, M.; Masselink, P. and Russell, P., 2016. Dynamics of rip currents associated with groynes - field measurements, modelling and implications for beach safety. Coastal Engineering, 107, 53-69.

Wright, L. and Short, A., 1984. Morphodynamic variability of surf zones and beaches: a synthesis. Marine Geology, 56, 93118. 